\title{
Intraspecific morphological variation between cultured and wild Clarias gariepinus (Burchell) (Clariidae, Siluriformes)
}

\author{
Shola G. Solomon, Victor T. Okomoda, Abel I. Ogbenyikwu
}

Received - 24 August 2014/Accepted - 14 January 2015. Published online: 31 March 2015; OInland Fisheries Institute in Olsztyn, Poland Citation: Solomon S.G., Okomoda V.T., Ogbenyikwu A.I. 2015 - Intraspecific morphological variation between cultured and wild Clarias gariepinus (Burchell) (Clariidae, Siluriformes) - Arch. Pol. Fish. 23: 53-61.

\begin{abstract}
This study was designed to evaluate morphological differences between cultured and wild African catfish, Clarias gariepinus (Burchell). Fish samples were collected from the lower Benue River (axis in Makurdi), while cultured fish were obtained from the University of Agriculture Makurdi research farm. The results revealed significant sex-related variation in the fish from different environments. Significant differences were observed in all morphometric parameters measured and in three of the five meristic counts recorded. Discriminant analysis and cluster analysis of morphometric parameters showed a high divergence among the populations, hence the tested fish samples were grouped into respective environments by sex. The meristic count, however, overlapped broadly showing no divergence among the populations. The morphometric differences between the cultured and wild African catfish could have been linked to genetic differences or environmental factors or a combination of both factors.
\end{abstract}

Keywords: African catfish, Benue River, morphometric parameters, meristic count

\section{Introduction}

Morphometric and meristic morphological characters are used widely to identify fish stocks (Turan et al. 2004), and they remain the simplest, most direct

\footnotetext{
S.G. Solomon [ $\Xi^{\circ}$ ], V.T. Okomoda, A.I. Ogbenyikwu

Department of Fisheries and Aquaculture

University of Agriculture, Makurdi, Nigeria

e-mail: solagabriel@yahoo.co.uk
}

methods of species identification. From previous studies (Creech 1992, Mamuris et al. 1998, Bronte et al. 1999, Hockaday et al. 2000), it is understood that the analysis of phenotypic variation in morphometric or meristic characters is the most commonly used method to delineate stocks of fish. It has often been used in discrimination and classification studies by statistical techniques (Agnew 1988, Avsar 1994). Despite the advent of techniques which directly examine biochemical or molecular genetic variation, these conventional methods continue to play an important role in stock identification even today (Swain and Foote 1999). Differences in the morphometric and meristic characters of a species from different regions can result from differences in genotypes, environmental factors operating on one genotype, or both of these acting together (Parish and Sharman 1958). While both morphometric and meristic characters respond to changes in environmental factors, their responses are different in some situations and can differ from species to species. The study of differences and variability in morphometric and meristic characters of fish stocks is important in phylogenetics and in providing information for subsequent studies on the genetic improvement of stocks.

The African catfish, Clarias gariepinus (Burchell), is a species of great economic importance as it is the most cultured catfish in Africa and the third most cultured catfish species in the world (

\footnotetext{
C Copyright by Stanisław Sakowicz Inland Fisheries Institute in Olsztyn.

(c) 2015 Author(s). This is an open access article licensed under the Creative Commons Attribution-NonCommercial-NoDerivs License (http://creativecommons.org/licenses/by-nc-nd/3.0/).
} 
Garibaldi 1996). At present, African catfish, especially C. gariepinus, are cultured in at least twelve African countries, and the most important producers are Mali, Nigeria, Ethiopia, and Ghana (Mathiesen 2012, Hecht 2013). It is also cultured in Asia (Thailand, Philippines, China, Israel, Malaysia, and Indonesia), in some parts of Europe (the Netherlands, the Czech Republic, Germany, Belgium, and Poland), and in Latin America, catfish is mainly produced in Brazil (Hecht et al. 1996).

According to Turan et al. (2006), decades of introduction and domestication of a fish species (especially those from the wild) leads to high adaptation to a wide range of geographical locations, which leads to phenotypic variations with respect to the pure stock (strains) of the brood stock. This is probably because of the effects of the environment or hybrids evolving through extensive inbreeding (El-Serafy et al. 2007). Although the comparisons of the morphology between reared and wild salmon stocks have already been conducted by a number of authors (Swain et al. 1991, von Cramon-Taubadel et al. 2005, Solem et al. 2006), there is a lack of information on the level of this variation for most tropical fish species. Difference among cultured and wild Clarias gariepinus stocks based on morphological characters have not yet been studied, and to our knowledge, this is the first such study focused on examining the extent of morphological variations of African catfish in cultured and wild environments.

\section{Materials and methods}

\section{Study area}

This experiment was carried out in the University of Agriculture, Makurdi (UAM) fishery research farm (Benue State, Nigeria). Makurdi is a town located at a latitude of $7^{\circ} 46^{\prime} \mathrm{N}$ and a longitude of $8^{\circ} 29^{\prime} \mathrm{E}$. Makurdi has two main seasons, the dry season which starts in October and ends in April, and the wet season which lasts from May until October. The average annual rain fall ranges from 1000 to $15000 \mathrm{~mm}$.

\section{Experimental fish and data collection}

Seventy mature $C$. gariepinus were collected from the wild (lower Benue River) and a cultured environment (UAM Fisheries research farm) using traps, gill nets, and cast nets. Meristic counts (numbers) and morphometric measurements $(\mathrm{mm})$ were performed as described by Teugels (1986).

The Fulton condition coefficient was calculated with the following formula:

$$
K=100 \times\left(\text { body weight }(\mathrm{g}) \times \text { standard length }^{-3}(\mathrm{~cm})\right)
$$

\section{Statistical analysis}

To ensure that variations in this study were only attributed to body shape differences, and not to the relative sizes of the fish, size effects from the data set were eliminated by standardizing the morphometric parameters using the allometric formula by Elliott et al. (1995):

$$
M_{a d j}=M \times\left(L s \times L o^{-1}\right)^{b} ;
$$

where $M$ is the original measurement, $M_{a d j}$ is the size-adjusted measurement, Lo is the TL of the fish, and Ls is the overall mean of the TL for all fish from all samples. Parameter b was estimated for each character from the observed data as the slope of the regression of $\log \mathrm{M}$ on $\log$ Lo using all the fish in all the groups. However, it has been established that meristic characters are independent of fish size, hence, they should not change during growth (Strauss 1985). Therefore, the raw data were analyzed without the transformation described above. Statistical analyses in the present study included descriptive statistics using Minitab 14 as well as univariate analysis of variance using Genstat ${ }^{\circledR}$ Discovery Edition 4 . Where significant differences occurred, Duncan's least significant difference test was used to separate the mean values of morphometric and meristic parameters. Morphometric and meristic data were subjected to discriminant function analysis (DFA) using Genstat ${ }^{\circledR}$ Discovery Edition 4. Minitab 14 software was used to generate two dendrograms with complete linkage and Euclidean distances for 
morphometric and meristic counts using means of samples collected from each environment per sex selected.

\section{Results}

The morphometric and meristic parameters of cultured and wild $C$. gariepinus are presented in Table 1 . The results reveal that there is a possible sex related difference in cultured and wild $C$. gariepinus. Cultured males had the highest value of 13 of the parameters measured, wild males and females where also observed to be higher in five of the parameters measured, while cultured females were only observed to be higher in two parameters. Dorsal fin and caudal fin rays did not show statistically significant differences between cultured and wild stocks in either sexes $(\mathrm{P}>0.05)$. Tables 2 and 3 show the relationship between various morphometric parameters and meristic counts of wild and cultured $C$. gariepinus, respectively. The results reveal that the size effect was completely eliminated in the species during analysis as there were no significant correlations between TL and SL with the other parameters measured. Relationships of the morphometric analysis among African catfish of different sexes of cultured and wild origin where considered according to the $1^{\text {st }}$ and $2^{\text {nd }}$ discriminant function (DF). The $1^{\text {st }}$ DF accounted for $59 \%$ and the $2^{\text {nd }}$ DF accounted for $31 \%$ of among-group variability, and together they explained $90 \%$ of total among-group variability.

Table 1

Mean $( \pm \mathrm{SD})$ morphometric and meristic characteristic measurements of cultured and wild C. gariepinus

\begin{tabular}{|c|c|c|c|c|c|}
\hline & $\begin{array}{l}\text { Cultured } \\
\text { female }\end{array}$ & $\begin{array}{l}\text { Cultured } \\
\text { male }\end{array}$ & Wild female & Wild male & $\mathrm{P}$ \\
\hline \multicolumn{6}{|l|}{ Morphometric parameters } \\
\hline Anal fin length & $15.58 \pm 0.26^{\mathrm{c}}$ & $19.17 \pm 0.5^{\mathrm{a}}$ & $15.17 \pm 0.49^{c}$ & $17.87 \pm 0.17^{\mathrm{b}}$ & 0.001 \\
\hline Dorsal fin length as $\%$ of standard length & $23.21 \pm 0.29^{b}$ & $26.64 \pm 0.29^{\mathrm{a}}$ & $23.36 \pm 0.65^{b}$ & $23.36 \pm 0.24^{\mathrm{b}}$ & 0.001 \\
\hline Head length & $10.39 \pm 0.15^{b}$ & $11.16 \pm 0.15^{\mathrm{a}}$ & $9.08 \pm 0.33^{\mathrm{c}}$ & $9.17 \pm 0.22^{\mathrm{c}}$ & 0.001 \\
\hline Body height & $5.25 \pm 0.11^{b}$ & $5.74 \pm 0.12^{\mathrm{a}}$ & $5.65 \pm 0.23^{\mathrm{a}}$ & $4.94 \pm 0.12^{b}$ & 0.001 \\
\hline Standard length & $36.80 \pm 0.76^{\mathrm{c}}$ & $41.96 \pm 0.41^{\mathrm{a}}$ & $34.23 \pm 1.1^{\mathrm{d}}$ & $38.62 \pm 0.19^{b}$ & 0.001 \\
\hline Total length & $42.05 \pm 0.63^{\mathrm{c}}$ & $47.25 \pm 0.46^{\mathrm{a}}$ & $38.13 \pm 1.13^{\mathrm{d}}$ & $43.29 \pm 0.26^{\mathrm{b}}$ & 0.032 \\
\hline Pectoral spine length & $3.16 \pm 0.08^{b}$ & $3.34 \pm 0.06^{\mathrm{b}}$ & $2.50 \pm 0.16^{\mathrm{c}}$ & $3.91 \pm 0.16^{\mathrm{a}}$ & 0.001 \\
\hline Eye diameter & $0.59 \pm 0.02^{\mathrm{c}}$ & $0.62 \pm 0.01^{\mathrm{b}}$ & $0.59 \pm 0.02^{\mathrm{c}}$ & $0.70 \pm 0.00^{\mathrm{a}}$ & 0.001 \\
\hline Pre anal distance & $19.24 \pm 0.33^{b}$ & $21.52 \pm 0.24^{\mathrm{a}}$ & $18.50 \pm 0.73^{\mathrm{c}}$ & $19.15 \pm 0.42^{b}$ & 0.001 \\
\hline Pre pelvic distance & $16.50 \pm 0.38^{b}$ & $18.65 \pm 0.16^{\mathrm{a}}$ & $16.61 \pm 0.56^{\mathrm{b}}$ & $17.12 \pm 0.34^{\mathrm{b}}$ & 0.001 \\
\hline Distance between the occipital process and dorsal fin & $2.00 \pm 0.06^{\mathrm{b}}$ & $2.15 \pm 0.02^{\mathrm{b}}$ & $2.34 \pm 0.1^{\mathrm{a}}$ & $2.45 \pm 0.06^{\mathrm{a}}$ & 0.001 \\
\hline Dorsal fin depth & $2.40 \pm 0.09^{c}$ & $2.89 \pm 0.08^{\mathrm{a}}$ & $2.61 \pm 0.05^{\mathrm{b}}$ & $2.50 \pm 0.06^{\mathrm{bc}}$ & 0.001 \\
\hline Caudal peduncle & $2.95 \pm 0.06^{\mathrm{c}}$ & $3.68 \pm 0.09^{\mathrm{a}}$ & $2.75 \pm 0.17^{\mathrm{c}}$ & $3.27 \pm 0.09^{b}$ & 0.001 \\
\hline Pelvic length & $2.49 \pm 0.09^{\mathrm{c}}$ & $2.59 \pm 0.10^{\mathrm{c}}$ & $3.11 \pm 0.13^{b}$ & $3.43 \pm 0.09^{\mathrm{a}}$ & 0.001 \\
\hline Weight & $525.00 \pm 20.06^{b}$ & $680.0 \pm 23.3^{\mathrm{a}}$ & $438.00 \pm 26.5^{c}$ & $364.00 \pm 22.4^{\mathrm{d}}$ & 0.001 \\
\hline Pre dorsal distance & $12.54 \pm 0.24^{\mathrm{b}}$ & $13.68 \pm 0.13^{\mathrm{a}}$ & $11.48 \pm 0.25^{\mathrm{c}}$ & $10.96 \pm 0.15^{\mathrm{d}}$ & 0.001 \\
\hline Condition factor $(\mathrm{K})$ & $0.702 \pm 0.01^{\mathrm{ab}}$ & $0.65 \pm 0.019^{b}$ & $0.809 \pm 0.057^{\mathrm{a}}$ & $0.45 \pm 0.03^{\mathrm{c}}$ & 0.001 \\
\hline \multicolumn{6}{|l|}{ Meristic count } \\
\hline Dorsal fin ray & $68.40 \pm 1.07$ & $67.75 \pm 1.04$ & $67.80 \pm 1.61$ & $65.27 \pm 0.83$ & 0.271 \\
\hline Anal fin ray & $51.70 \pm 0.59^{c}$ & $52.65 \pm 0.51^{\mathrm{b}}$ & $54.07 \pm 0.59^{\mathrm{a}}$ & $50.47 \pm 0.29^{d}$ & 0.001 \\
\hline Caudal fin ray & $17.90 \pm 0.29$ & $18.25 \pm 0.32$ & $18.40 \pm 0.34$ & $18.16 \pm 0.18$ & 0.674 \\
\hline Pectoral fin ray & $8.50 \pm 0.29^{b}$ & $8.7 \pm 0.15^{b}$ & $7.80 \pm 0.51^{\mathrm{a}}$ & $8.53 \pm 0.13^{\mathrm{a}}$ & 0.001 \\
\hline Pelvic fin ray & $5.30 \pm 0.15^{\mathrm{ab}}$ & $5.55 \pm 0.14^{\mathrm{a}}$ & $5.73 \pm 0.42^{\mathrm{a}}$ & $4.83 \pm 0.08^{b}$ & 0.041 \\
\hline
\end{tabular}

Means in the same column with different superscripts differ significantly $(\mathrm{P}<0.05)$ 


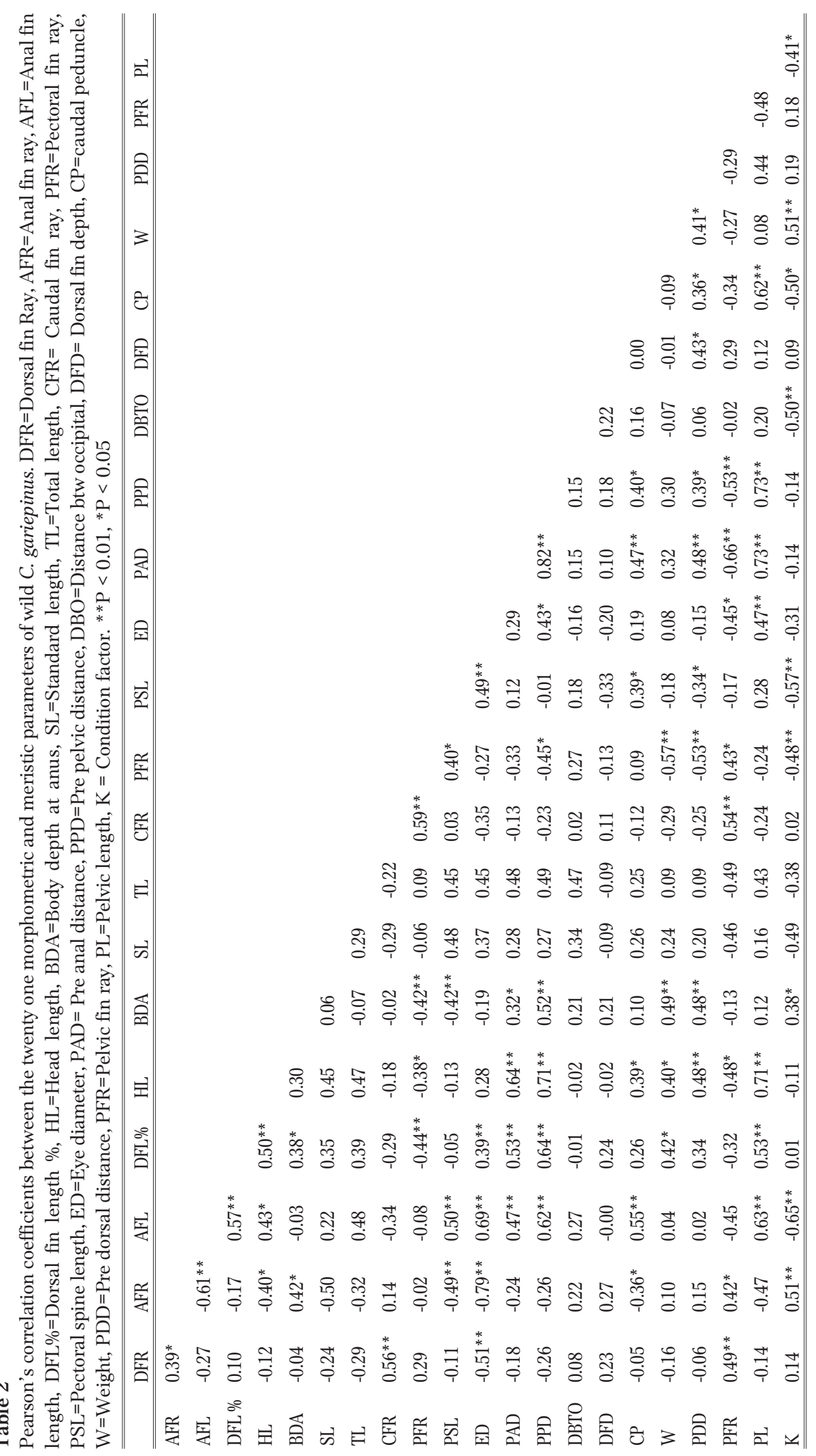




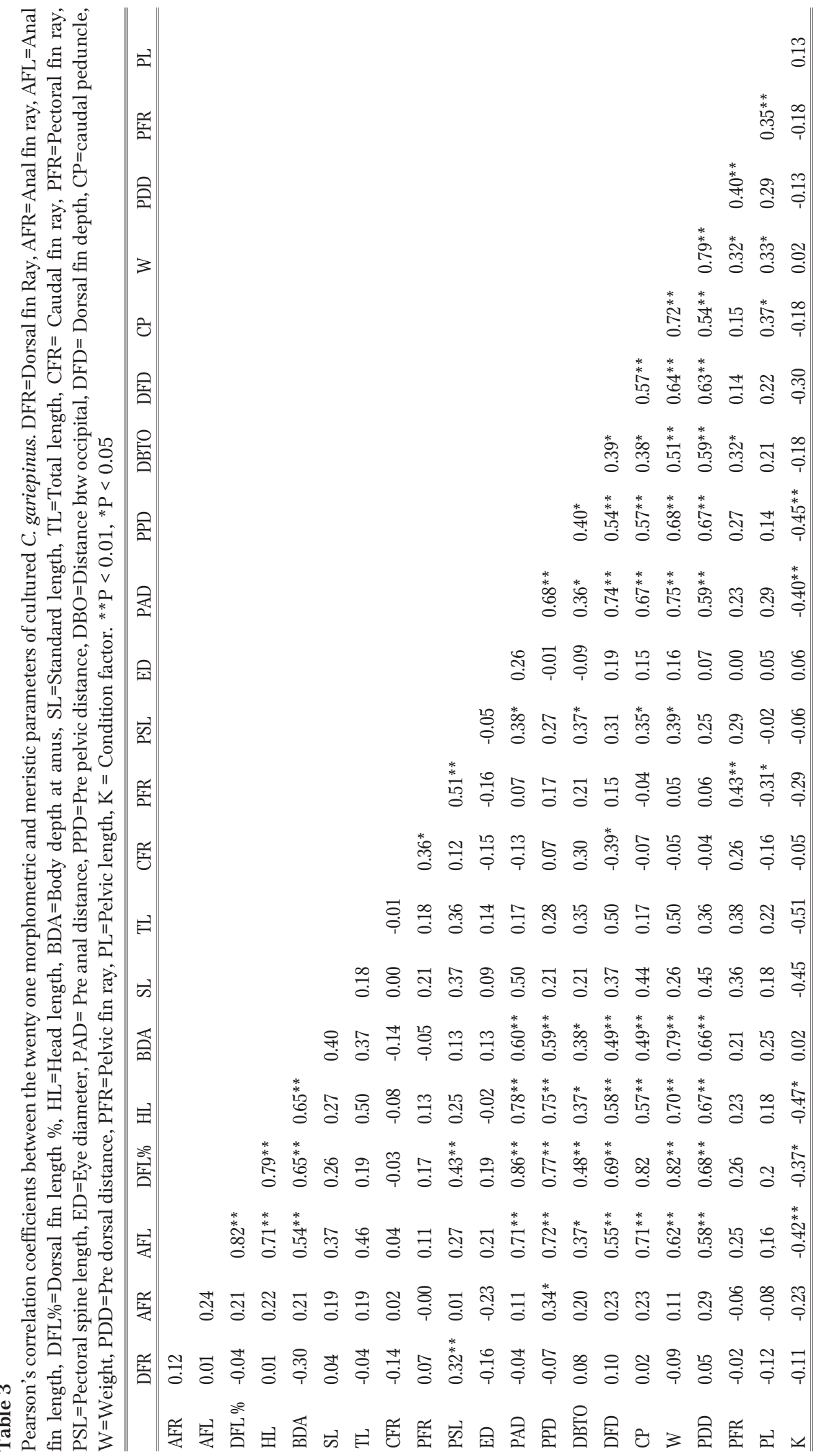




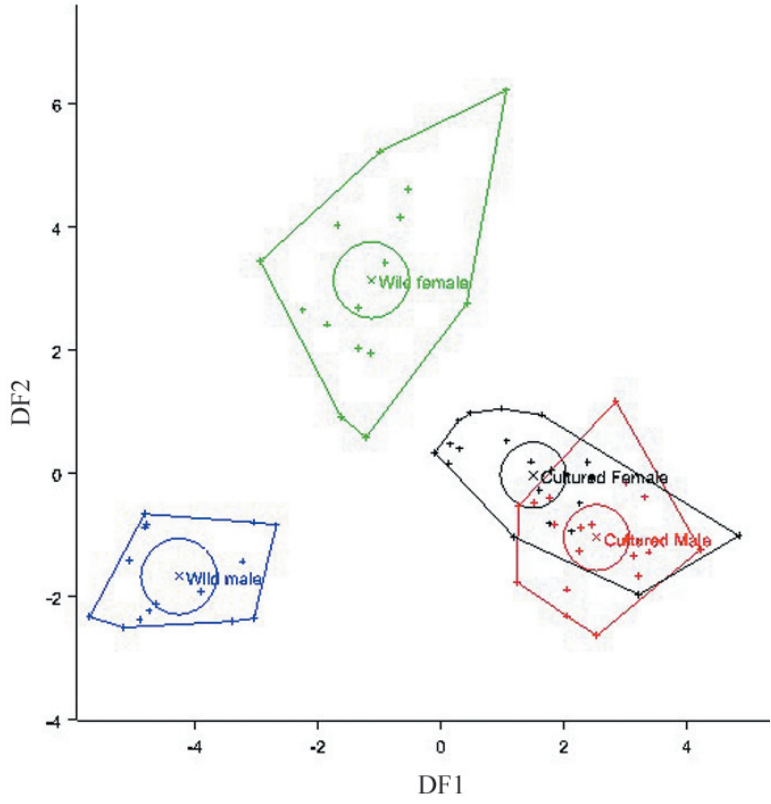

Figure 1. Sample centroids of the discriminant function scores based on morphometric and meristic measurements of wild and cultured C. gariepinus.

According to the canonical discriminant function coefficients obtained for the morphometric data, the most influential variables for $1^{\text {st }}$ DF were HL, BDA, and ED. Plots of canonical discriminant functions 1 of the morphometric measurements (Fig. 1) clearly showed a complete separation between the wild and cultured populations of African catfish. The two sexes were well separated and absolutely differentiated along the first function for wild, but there was noticeable sex overlap for cultured. Considering the $2^{\text {nd }} \mathrm{DF}$, the cultured fish displayed intermediate

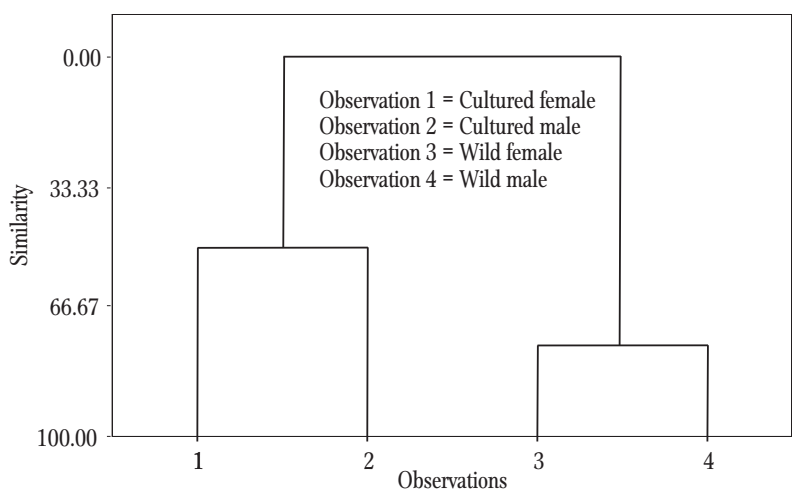

Figure 2. Dendrogram with complete linkage and euclidean distance for morphometric parameters of wild and cultured $C$. gariepinus. characteristics between the sexes of the wild stock with cultured males overlapping broadly with wild males, while cultured females overlapped slightly with wild females. However, while culture male and female stocks slightly overlapped with each other, their wild counterparts clearly differentiated from one another. On the other hand, the dendrogram of complete linkage and euclidean distance showed clusters between sexes of cultured African catfish at 50.89 and wild African catfish at 76.47 (Fig. 2). For the meristic count, the $1^{\text {st }} \mathrm{DF}$ accounted for $86 \%$ and the $2^{\text {nd }}$ DF accounted for $10 \%$ of among-group variability for the morphometric parameters measured, and together they explained $96 \%$ of the total among-group variability. According to the canonical discriminant function coefficients obtained for the meristic data, the most influential variables for the $1^{\text {st }}$ DF were DFR, AFR, PFR, and CFR. Plots of canonical DF 1 and 2 of the meristic measurements (Fig. 3) showed a broad overlap between the wild and cultured broodstocks of African catfish of different sexes, but with indications $\left(1^{\text {st }} \mathrm{DF}\right)$ of intermediate relationships of cultured African catfish (both sexes) with male and female wild counterparts. This is further buttressed by the dendrogram for meristic parameters with the cluster between the sexes of

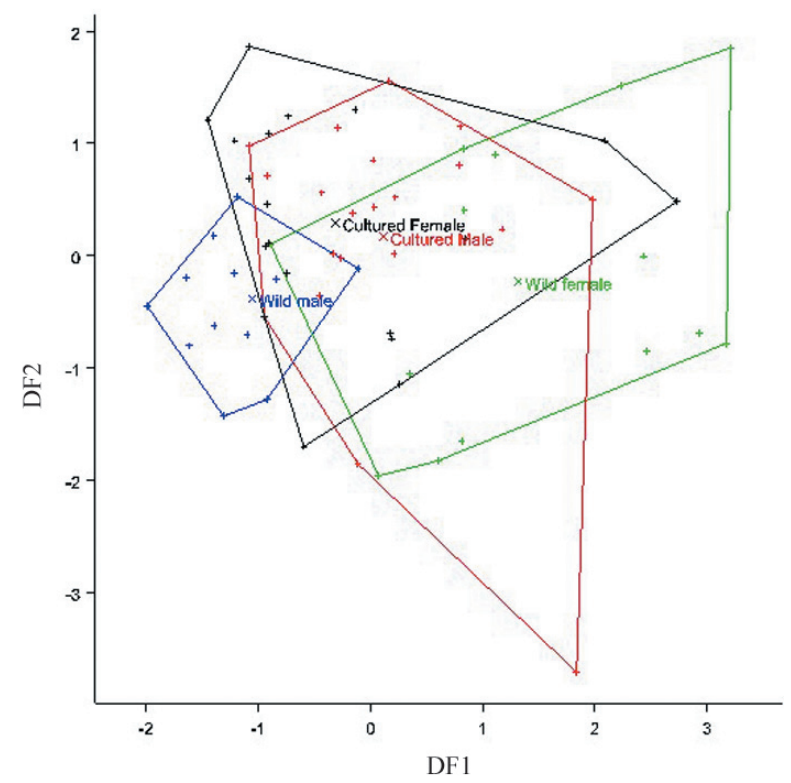

Figure 3. Sample centroids of the discriminant function scores based on meristic measurements of wild and cultured $C$. gariepinus. 


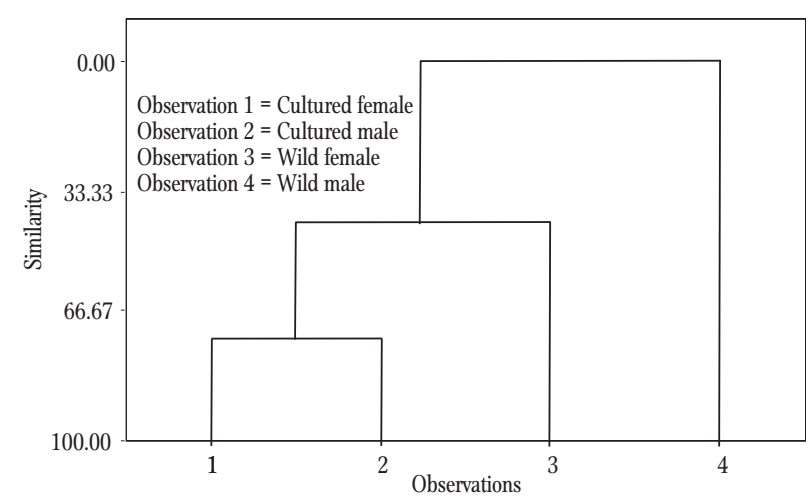

Figure 4. Dendrogram with complete linkage and euclidean distance for meristic count of wild and cultured $C$. gariepinus.

cultured African catfish at 72.68 and also the cluster with the wild female African catfish at 42.34 (Fig. 4).

\section{Discussion}

Fish is most susceptible to environmentally induced morphological variations; hence, they demonstrate greater variances within and between populations than do any other vertebrate (Allendorf et al. 1987, Wimberger 1992). This study reveals the phenotypic plasticity of African catfish to be high within sexes and for different culture environments. This contradicts the report by Turan et al. (2005) of negligible sex variation in $C$. gariepinus from six wild populations in Turkey. Patiyal et al. (2014) also reported that sex related variation does not exist in wild and captive stocks of endangered Putitor mahseer, Tor putitora (Hamilton). This study recorded significant differences in all morphometric parameters and in three of five meristic counts. Stearns (1983) reports that fish adapt quickly by modifying their physiology and behavior to environmental changes hence changing their morphology. It may be ideal to infer that the fish stock examined in this study had made morphological modifications to better adapt to their present environmental conditions. The high value of the weight of the cultured stock recorded in this study can be linked to artificial feeding provided while the high condition factor of female fish was likely due to the gonad condition of the female (gravid). Allendorf and Phelps (1988), Swain et al. (1991), and Wimberger (1992) highlight environmental conditions such as food abundance and temperature as causes of fish morphological plasticity. Morphometric differences among stocks have also been linked to differences in geographical and ancestral origins by Hossain et al. (2010). However, breeding over several years may have diluted the initial gene pool of the domesticated fish leading to genetic variation (translated to morphological differences). This is why genetic studies are required to establish these facts. Turan et al. (2004) reports similar findings for Liza abu (Heckel) populations from the Orontes, Euphrates, and Tigris rivers in Turkey. They concluded that decades of introduction and domestication of $L$. abu has lead to high adaptation to a wide range of geographical locations that are shown in phenotypic variations with respect to the pure strains. El-Serafy et al. (2007) reports that hybridization through extensive inbreeding is a possible course of morphological variation. It is an established fact that most cultured African fish species have been genetically polluted (Olufeagba et al. 2002), hence, this could have lead to the remarkable phenotypic changes in this study.

The variations observed in correlation coefficients of the morphometric and meristic data for wild and cultured catfish could be linked strongly to feeding pattern, morphometric placidity, environmental stressors, and genetic variability (as explained earlier). Studies on the morphometric and meristic relationships of fishes are very few, but there is sufficient evidence to prove that this likely varies among different species and culture environments. The results of the present study reveal low or no variability in meristic counts compared to morphometric characters (Figs. 1 and 2). It is clear that meristic counts overlapped so widely among the sexes from the different culture environments so that the populations could not be discriminated by sex or by culture environment. In contrast, analyses of morphometric characters revealed abundant variation among populations. Discriminant analyses showed obvious morphological differences between the fish collected from the wild and, obtained from culture. The fish 
clustered into four distinct groups. Vidalis et al. (1994) argued that meristic characters can follow a predetermined variability at a very narrow range, because divergence of meristic counts from a standard range could be fatal. Misra and Carscadden (1987) stated that several authors considered meristic characters less useful when comparing morphological variations. Morphometrics of the head and body depth have been regarded as the most important characters for discrimination of angler fish, Lophius vomerinus Val., Pacific herring Clupea pallasi Val., and Orange roughy, Hoplostethus atlanticus Collett (Leslie and Grant 1990, Schweigert 1990, Haddon and Willis 1995), while Turan et al. (2005) revealed that morphometric differentiation among samples from Turkish waters was largely located in the head of $C$. gariepinus. Nevertheless, fish generally demonstrate greater variance in morphological traits both within the same species, different species, and between populations than do any other vertebrate. This largely reflects differences in feeding environments, prey types, food availability, and other features (Dunham et al. 1979, Allendorf 1988, Thompson 1991, Wimberger 1992). More research, especially genetic studies, are needed to better understand the effect environment can have on the morphometric parameters of wild and cultured African catfish.

Author contibutions. S.G.S. conceived and designed research experiments, V.T.O. analyzed the data and wrote the paper, A.I.O performed research.

\section{References}

Agnew D.J. 1988 - Evidence for the existence of two populations of Irish Sea cod (Gadus morhua L.) from consideration of growth rates - ICES Committee Meeting Papers 1988/G 65, p. 20.

Allendorf F.W., Phelps S.R. 1988 - Loss of genetic variation in hatchery stock of cutthroat trout - Trans. Am. Fish. Soc. 109: 537-543.

Allendorf F.W., Ryman N., Utter F. 1987 - Genetics and fishery management: past, present and future - In: Population genetics and fisheries management (Eds) U. Ryman,
F. Utter, Washington D.C., University of Washington Press: 1-19.

Allendorf F.W. 1988 - Conservation biology of fishes Conserv. Biol. 2: 145-148.

Avsar D. 1994 - Stock differentiation study of the sprat off the southern coast of the Black Sea - Fish. Res. 19: 363-378.

Bronte C.R., Fleischer G.W., Maistrenko S.G., Pronin N.M. 1999 - Stock structure of Lake Baikal omul as determined by whole body morphology - J. Fish Biol. 54: 787-798.

Creech S. 1992 - A multivariate morphometric investigation of Atherina boyeri Risso, 1810 and A. presbyter Cuvier, 1829 (Teleostei: Atherinidae): morphometric evidence in support of the two species - J. Fish Biol. 41: 341-353.

Dunham A.E., Smith G.R., Taylor J.N. 1979 - Evidence for ecological character displacement in western American catostomid fishes - Evolution 33: 877-896.

El-Serafy S.S., Abdel-Hameid N.-A.H., Awwad M.H., Azab M.S. 2007 - DNA riboprinting analysis of Tilapia species and their hybrids using restriction fragment length polymorphisms of the small subunit ribosomal DNA Aquac. Res. 38: 295-303.

Elliott N.G., Haskard, K., Koslow, J.A. 1995 - Morphometric analysis of orange roughy (Hoplostethus atlanticus) off the continental slope of southern Australia - J. Fish Biol. 46: 202-220.

Garibaldi L. 1996 - List of animal species used in aquaculture - FAO Fisheries Circular 914.

Haddon M., Willis T.J. 1995 - Morphometric and meristic comparison of orange roughy (Hoplostethus atlanticus: Trachichthyidae) from the Puysegur Bank and Lord Howe Rise, New Zealand, and its implications for stock structure - Mar. Biol. 123: 19-27.

Hecht T. 2013 - A review of on-farm feed management practices for North African catfish (Clarias gariepinus) in sub-Saharan Africa - In: On-farm feeding and feed management in aquaculture (Eds) M.R. Hasan, M.B. New, FAO Fisheries and Aquaculture Technical Paper No. 583. Rome: 463-479.

Hecht T., Oellermann L., Verheust L. 1996 - Perpectives on clariid catfish culture in Africa - Aquat. Living Resour. 9: 197-206.

Hockaday S., Beddow T.A., Stone M., Hancock P., Ross L.G. 2000 - Using truss networks to estimate the biomass of Oreochromis niloticus and to investigate shape characters - J. Fish Biol. 57: 981-1000.

Hossain M.A.R., Nahiduzzaman M., Saha D. Habiba Khanam M.U., Alam M.S. 2010 - Landmark-Based morphometric and meristic Variations of the Endangered Carp, Kalibaus Labeo calbasu, from Stocks of Two Isolated Rivers, the Jamuna and Halda, and a Hatchery - Zool. Stud. 49: 556-563.

Leslie C.C., Grant W.S. 1990 - Lack of congruence between genetic and morphological stock structure of the 
Southern African anglerfish Lophius vomerinus - South Afr. J. Mar. Sci. 9, 379-398.

Mamuris Z., Apostolidis A.P., Panagiotaki P., Theodorou A.J., Triantaphllidis C. 1998 - Morphological variation between red mullet populations in Greece - J. Fish Biol. 52: 107-117.

Mathiesen A.M. 2012 - The State of the World Fisheries and Aquaculture 2012 - Food and Agriculture Organization.

Misra R.K., Carscadden J.E. 1987 - A multivariate analysis of morphometrics to detect differences in populations of capelin (Mallotus villosus) - J. Cons. Int. Expl. Mer. 43: 99-106.

Olufeagba S.O., Aluko P.O., Eyo A.A. 2002 - Dietary protein requirements of triploid Heterobranchus - J. Aquat Sci. 17: 1-4.

Parish B.B., Sharman D.P. 1958 - Some remark on method used in herring 'racial' investigations, with special reference to otolith studies - Rapp. P.-V. Réun. Cons. Int. Explor. Mer. 143: 66-80.

Patiyal R.S., Mir J.I., Sharma R.C., Chandra S., Mahanta, P.C. 2014 - Pattern of meristic and morphometric variations between wild and captive stocks of endangered Tor putitora (Hamilton 1822) using multivariate statistical analysis methods - Proc. Natl Acad. Sci., India, Sect. B Biol. Sci. 84: 123-129.

Schweigert J.F. 1990 - Comparison of morphometric and meristic data against truss networks for describing Pacific herring stocks - Am. Fish. Soc. Symp. 7: 47-62.

Solem Ø., Berg O.K., Kjøsnes A.J. 2006 - Interand intra-population morphological differences between wild and farmed Atlantic salmon juveniles - J. Fish Biol. 69: 1466-1481.

Stearns S.C. 1983 - A natural experiment in life-history evolution: field data on the introduction of mosquitofish (Gambusia affinis) to Hawaii - Evolution 37: 601-617.

Strauss R.E. 1985 - Evolutionary allometry and variation in body form in the South American catfish genus Corydoras (Callichthydae) - Syst. Biol. 34: 381-396.
Swain D.P., Ridell B.E., Murray C.B. 1991 - Morphological differences between hatchery and wild populations of coho salmon (Oncorhynchus kisutch): environmental versus genetic origin - Can. J. Fish. Aquat. Sci. 48: 1783-1791.

Swain D.P., Foote C.J. 1999 - Stocks and chameleons the use of phenotypic variation in stock identification - Fish. Res. 43: 113-128.

Teugels G.G. 1986 - A systematic revision of the African species of the genus Clarias (Pisces; Clariidae) - Ann. Mus. R. Afr. Centr. 247: 1-199.

Thompson J.D. 1991 - Phenotypic plasticity as a component of evolutionary change - Trends Ecol. Evol. 6: 246-249.

Turan C., Erguden D., Turan F., Gurlek M. 2004 - Genetic and morphologic structure of Liza abu (Heckel, 1843) populations from the Rivers Orontes, Euphrates and Tigris - Turk. J. Vet. Anim. Sci. 28: 729-734.

Turan C., Yalcin S., Turan F., Okur E., Akyurt I. 2005 Morphometric comparisons of African catfish, Clarias gariepinus populations in Turkey - Folia. Zool. 54: 165-172.

Turan C., Oral M., Ozturk B., Duzgunes E. 2006 Morphometric and meristic variation between stocks of bluefish (Pomatomus saltatrix) in the Black, Marmara, Aegean and northeastern Mediterranean Seas - Fish. Res. 79: 139-147.

Vidalis K., Markakis G., Tsimenides N. 1994 - Discrimination between populations of picarel (Spicara smaris L., 1758) in the Aegean Sea, using multivariate analysis of phonetic characters - Fish. Res. 30: 191-197.

von Cramon-Taubadel N.V., Ling E.N., Cotter D., Wilkins N.P. 2005 - Determination of body shape variation in Irish hatchery-reared and wild Atlantic salmon - J Fish Biol. 66: 1471-1482.

Wimberger P.H. 1992 - Plasticity of fish body shape, the effects of diet, development, family and age in two species of Geophagus (Pisces: Cichlidae) - Biol. J. Linn. Soc. 45: 197-218. 